\title{
Poemas Inéditos
}

João Edson Rufino

\section{Infanticídio}

Meu pai não montava a cavalo

Eu nem o conheci

Como tantos,

Fez filhos e deixou um em cada favela

É bom contar esses feitos na roda dos comparsas.

Acentua o machismo dos homens inconseqüentes.

Mulher? Ela que se vire.

A minha mãe não costurava no silêncio da casa.

Não havia silêncio. Havia balas cortando os becos e vielas

E nosso corpo podendo ser atravessado

A qualquer momento por uma delas.

Mama desdobrava-se em dez

Para dar de comer a dezenas.

Não tive Preta Velha para pôr o café

Nem mesmo para pôr-me a ninar.

Contar-me estórias que só em África existem.

Aqui, morre-se cedo. É resistente quem chega aos doze.

São dúzias de nós que morremos todos os dias.

Não sei se a minha história

É mais alegre ou triste que a de Crusoé.

Não sou poeta

E nem sei se o que trago na memória

História é. 


\section{Ser Negro}

Ser negro é travessia

O translado da África

Plantado em terra vermelha

Fincado em força e fogo.

Chega de desesperança, fome, solidão e morte

Chega de tanta lamentação

A minha vida eu mesmo invento

Sou altivo, forte

Não só noites do norte

Minhas noites têm mais amplidão.

Basta de estigma, de gueto, da marca registrada

Do lamento, do falso sentimento, do negro-televisão

Não me interessa esta festa,

Execro premiações estereotipadas.

Dispenso a fútil animação.

Já não perco o meu tempo

Ando meio sem paciência

Há lugares em que entro

E inquietam-se com minha presença

(Quem é? De onde veio? Como conseguiu?)

Minha genealogia não está na senzala

Sou pensador, eclético, não-canônico, imprevisível

Princesas? Senhores? Discursos? Abolições?

Ser negro é não crer em ilusões. 